\title{
Ağırnas Topraklarının Puzolanik Aktivitesi
}

Yrd. Doç. Sedat Kurugöl

MSGSÜ, Meslek Yüksek Okulu, Mimari Restorasyon Programı

\section{1- Giriş, tarihi bilgiler}

Kayseri ilimizin yaklaşık 20-25 km. doğu bölgesinde bulunan, Mimar Sinan'in doğum yeri de olan Ağırnas'ın ve bölgedeki yerleşimin tarihinin M.Ö 20003000'lü yıllara kadar uzandığı belirtilmektedir (Cömert, 2005, 402). Bölgenin, eski Kaniş (Kültepe)-Karum yerleşim sahasına yakınlığ 1 , bugün birçoğunun üzerine evler yapılmış yeraltı dehliz ve mağaraların varlığ kadar gidebileceğini düşündürmektedir.

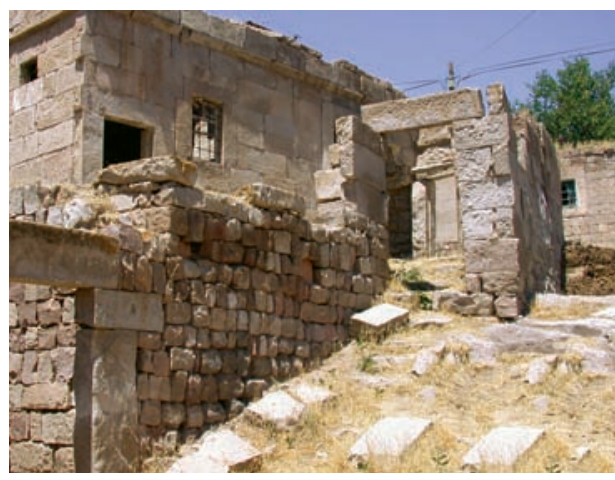

Resim: 1

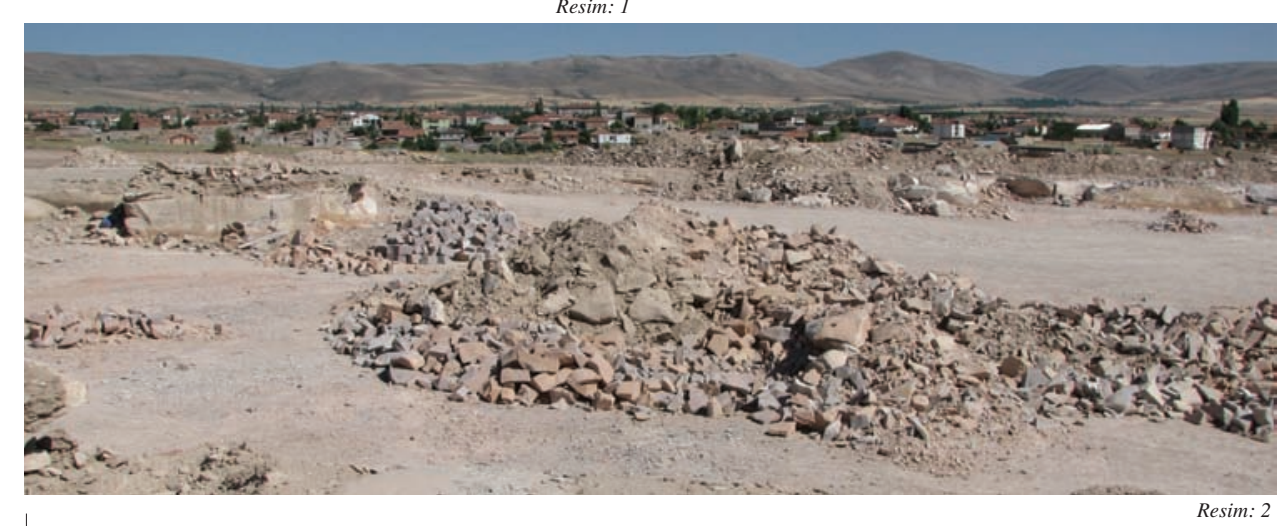

12 Sayı 7, Mayıs 2009

Tarihsel süreç içinde bölgede yaşamış çeşitli uygarlıklar yapı teknolojilerinde doğal çevrenin sunmuş olduğu çeşitli malzemelerden yararlanmışlar ve yapılarını bu malzemeleri kullanarak inşa etmişlerdir (Resim-1).

Tüm Kayseri civarı jeolojik olarak volkanik faaliyetler sonucu şekillenmiş bir arazi yapısına sahiptir. Ağırnas vadisinin sağ ve sol yamaçları, beyaz ve kırmızıya yakın çeşitli renklerde yumuşak bazalt ve magmatik tüflerle kaplıdır (Cömert, 2005,401) (Resim-2). İgnimbirit (1) olarak bilinen bu tüfler aynı zamanda yapı taşı olarak da kullanılmış ve yörenin mimarisinin şekillenmesine de damgasını vurmuştur. Ağırnas bölgesi, değişik yaşlardaki bu volkanik kayaçlardan başka, tortul kökenli alçıtaşı, kireçtaşı ve kil yatakları bakımından da zengin bir konuma sahiptir. Ayrıca çeşitli renk ve

sim: 2
Ağırnas ve civarındaki yapıların harç uygulamalarında kullanılan temel bağlayıcının alçı olduğu bilinmekle birlikte, kireç bağlayıcılı uygulamalara da rastlanmaktadır. Eski dönemlere ait yer altı şehirlerinde şarap üretiminin yapıldığı mekanlarda taş zemine açılmış yaklaşık 100 x 100 x 80 - 90

$\mathrm{cm}$. boyutlarında şırahane çukurların iç yüzeylerine uygulanmış sıvadan alınan örnek üzerinde yapılan analizler sonucu bu sıvanın kireç esaslı olduğu ve hidrolik bir özellik gösterdiği tesbit edilmiştir. Eski dönemlerde uygulanan kireç esaslı harçlar içerisine, bölgenin volkanik topraklarından katılmış olabileceği düşünülmüş, yöredek toprakların puzolanik bir aktiviteye sahip olup olmadıklarının belirlemek amacıyla Ağırnas'ın çeşitli yerlerinden 4 farklı toprak örneği alınmış ve bunlar üzerinde ilgili Türk Standardı TS-25 uyarınca puzolanik aktivite deneyleri yapılmıştır. Deneyler sonucunda tüm toprak örneklerin çeşitli oranlarda puzolanik özelliklere sahip olduğu ve mekanik deneyler sonucunda elde edilen değerlerin standardın öngördüğü minimum değerleri sağladığı saptanmıştır. Summary:

Although the basic binder is gypsum and lime at plaster and mortar application of building technologies around Agirnas, plaster applications with limestone binder are also found. The plaster samples were taken from the inner surfaces of wine inns sized as $1 \times 1 \mathrm{~m}$ sizes and 0,8-0,9 $\mathrm{m}$ at which are found in underground cities of ancient civilizations the samples from these inns are slaked lime based and present hydrolytic character. It is supposed that regional volcanic soils are also added to these slaked lime plasters which were taken from several places of Agirnas. The pozzolanic activity test was done upon them according to he related Turkish Standard, TS-25. At the end of the tests, it is confirmed that all the soil samples have pozzolanic activity and the values taken from mechanical tests satisfy the minimum values which are stipulated by related standard. Anahtar Kelimeler: Ağırnas toprakları, puzolan, sıva, harç, puzolanik aktivite, mekanik özellikler Keywords:

Ağırnas soils, pozzolans, plaster, mortar, pozzolanic activity, mechanical properties 
Resim: I Ağırnas'ın geleneksel taş yapılarından örnek

Resim: 2

Taş ocaklarından

Ağırnas'ın genel görünüşü

Resim: 3

Taş yüzeye uygulanan toprak siva ve firpi toprakla yapılmıs badana boyası

Resim: 4 Eski alf̧ı ocağı ve alf̧ı taşları

Resim: 5

Terkedilmiş eski alf̧ı fırınları özelliklerdeki topraklara sahip olmasıyla da dikkati çekmektedir.

\subsection{Harçlar ve sivalar}

Bölgenin geleneksel taş yapılarının

harç uygulamalarında alçı ve kireç

bağlayıcısının kullanıldığı görülmektedir.

Taş yapıların iç yüzeyleri toprak esaslı

(genellikle gebik toprak) sıvalarla sıvanmış, dış

yüzeyler ise çoğunlukla sıvasız

bırakılmıştır. İçerisine saman,

kıtık gibi çeşitli organik lif malzemeler

katılarak yapılan bu toprak sıvalar,

yüzeyin durumuna göre çeşitli kalınlıklara

sahip olabilmektedir. Bu sıvanın üzeri de, sıva ile iyi bir aderans gösterdiği tespit edilen ve "Çırpı Toprağı"(2) adı verilen beyaz renkli toprakla hazırlanan bir boya tabakası ile örtülmüsştür (Resim-3).

A ğırnas'ın taş yapılarında, çoğunlukla taşların aralıklarını doldurmada ve derz uygulamalarda kullanılmış olan alçı, "Alçılık" adı verilen ve Ağırnas'ın doğusunda yer alan bölgedeki alçı taşı yataklarından elde edilmiştir (Resim-4). Ocakların hemen yakınlarında da dört adet eski alçı fırını bulunmaktadır (Resim-5). Ayrıca Koramaz Dağı'nın Gereme Köyü’ne uzanan yamaçlarının

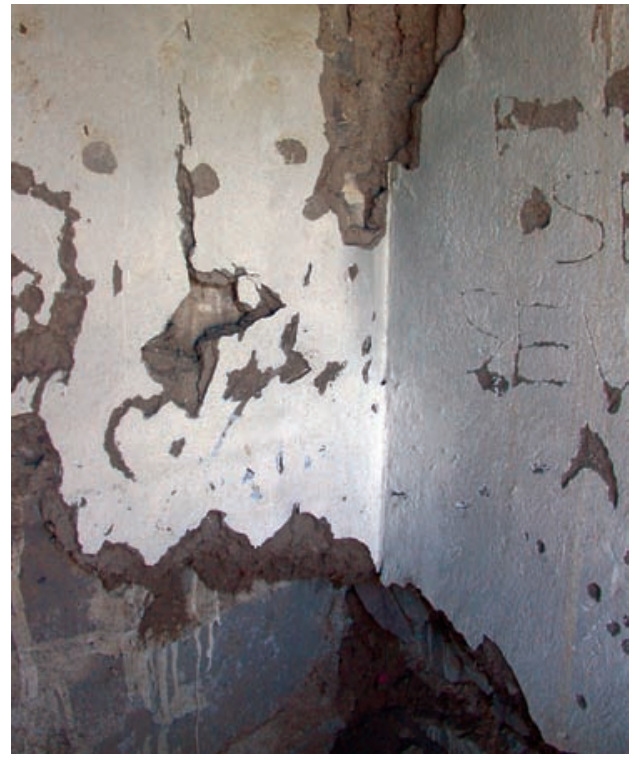

I ODTÜ, Jeoloji-Jeofizik Araştırma Merkezi'nde yapilan petrografik analizlere göre Ä̆ınas'da yapı taşı olarak kullanilan tas türünün, volkanik bir tüf türü olan Ignimbirit yada kaynaklı tüf olduğu tesbit edilmiştir. Taş üzerinde yapilan mikroskobik analizler sonucu tasin cok ince taneli bir çimento hamuru içinde yer alan magmatik korozyonlu sanidin, Plajioklas, Hornblend fenokristalleri yanında f̧ok ince taneli opak mineraller içerdiği hamurun en büyük bölümünü paralel düzenlenmis ve yassılaşmıs volkanik cam kıymıklarından oluştuğu, az miktarda volkanik kaya parçası bulunduğu ve örneklerde çatlak ve damara rastlanmadı ̌ tesbit edilmiștir.

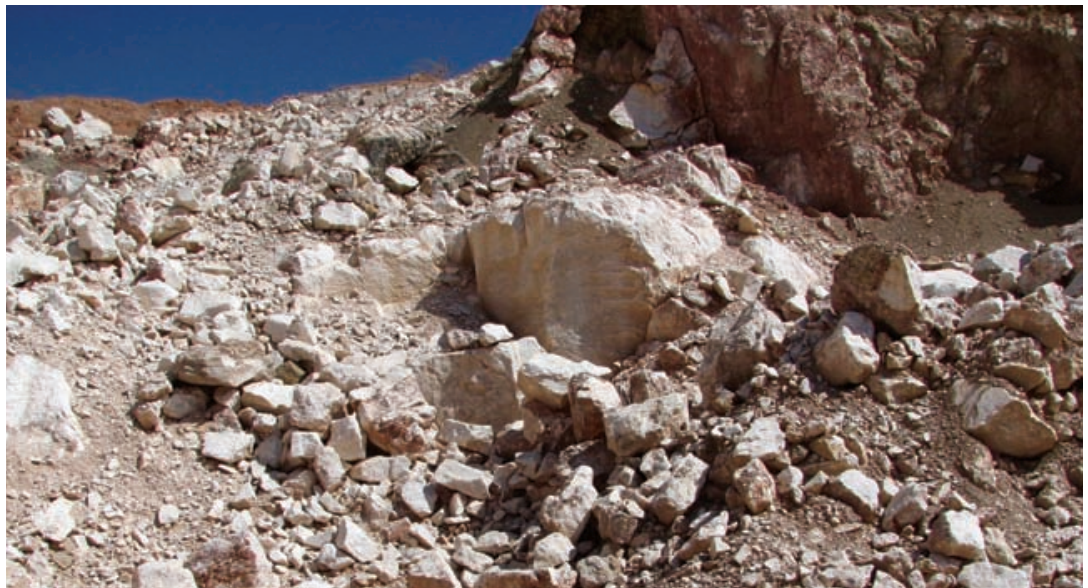

Resim: 4

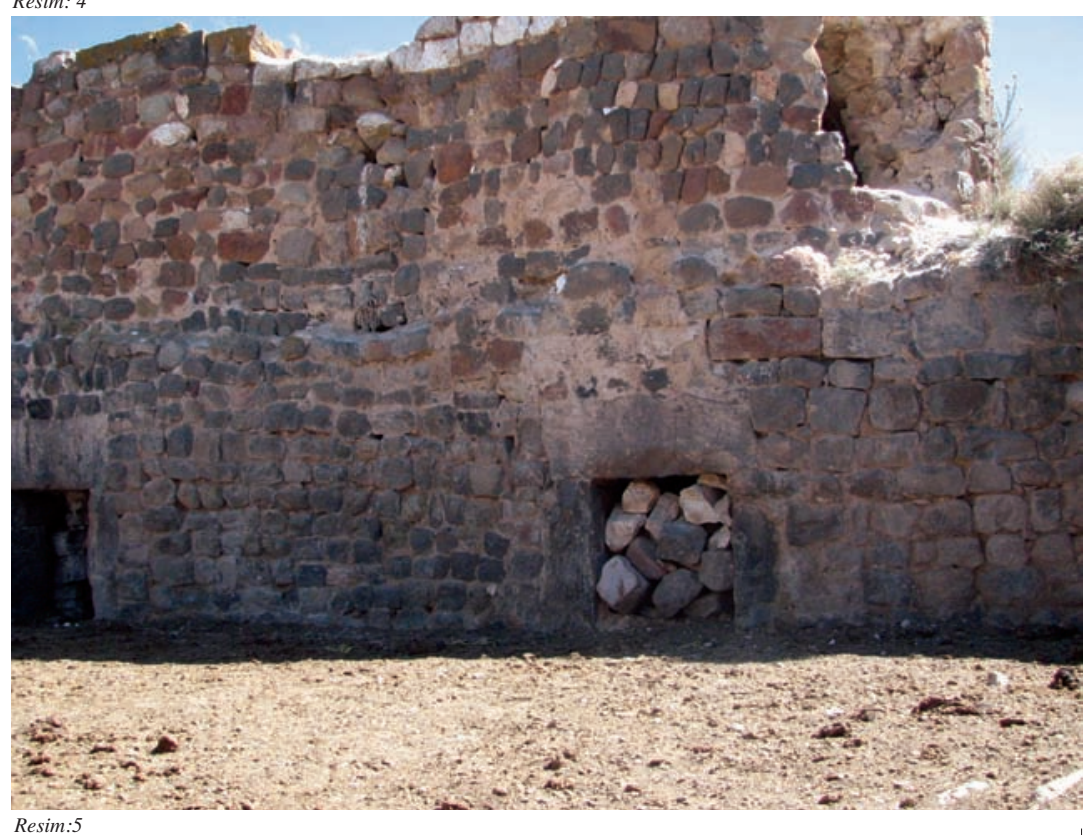

Sayı 7, Mayıs 2009 I3 
eteklerinde çok sayıda kireç ve alçı ocağına rastlanmaktadır. Alçı ocakları ve fırınlar bugün terkedilmiş bir görünüm sergilemekte ve artık üretim yapılmamaktadır. Dolayısıyla bir zamanlar Ağırnas'ın ve civardaki yerleşkelerin gereksinim duyduğu alçı ve kireç bağlayıcıların üretiminin buralarda yapıldığı söylenebilir.

Bilindiği gibi Anadolumuzun çeşitli yörelerinde alçıdan üretilen ve "Tatlı Sıva" olarak da adlandırılan bir sıva ve harç türü mevcuttur. Bu malzeme, içerisine bir miktar kireç de katılarak üretilmiştir. Örneğin, Beypazarı geleneksel evlerinin tüm ahşap karkas ve kerpiç duvarlarının iç ve dış yüzeylerinde tatlı sıvalar kullanılmıștır.

Bu sıvanın bağlayıcı hammaddesi de Beypazarı yöresindeki alçı taşı yataklarından temin edilmiştir (Urak vd. 2005, 403). Kagir malzemeyle de iyi bir aderans gösterebilen ve atmosfer koşullarına dayanıklı olan bu sıvaların dış yüzeylerde de uygulandığ 1 görülmektedir. Ağırnas'da, alçıyla yapılan uygulamaların da buna benzer bir özellik gösterdiği anlaşılmaktadır (Resim-6). Çünkü taşların derz ve aralıklarında kullanılmış olan bu malzemenin dış koşulların olumsuz etkisiyle önemli bir ayrışmaya uğramadığı tespit edilmiştir.

Taş yapılar inşa edilirken taşların yan yüzeylerinin ortasından geçecek şekilde külünkle "kuyruk yuvası" adı verilen küçük oyuklar açılır ve taşlar bir sıra dizildikten sonra çok ince kumla karıştırılmış ve süt kıvamında hazırlanmış alçı harcı bu oyuklara dökülür, örme işlemi süresince bu işleme devam edilirdi. Böylece taşlar arasındaki tüm boşluklar bu harçla dolar ve taşların tüm yüzeylerin birbirleriyle teması ve aderansı böylelikle sağlanmış olurdu.
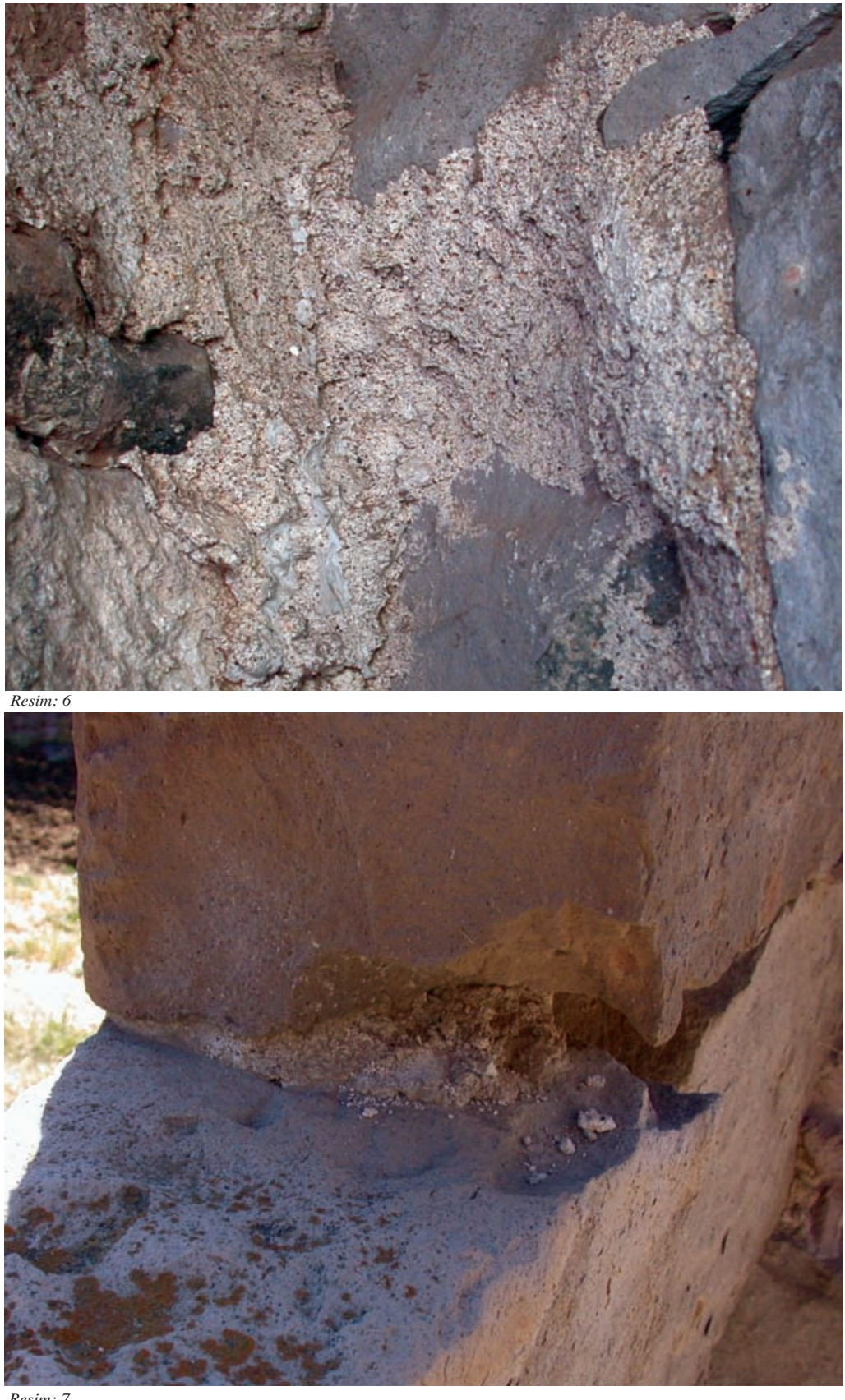

Yörenin eski taș ustalarının ifadesine göre bu harcın oluşturulmasında hacimce 1 birim alçı ve 2 birim çok ince taneli kum katılıyor ve uygulanacağı yere göre gerekli miktarda su ilave edilerek kıvam ayarlanıyordu. Bu malzeme çoğunlukla, belirtildiği gibi, kesme taş aralıklarının ve kısmen de çeşitli taş yüzeylerdeki boşlukların doldurulmasında kullanılmıştır.
Resim: 6

Duvar örgü sisteminde alçı harcı Resim: 7

Kireç harcı ile örülmüş duvarlara örnek

14 Sayı 7, Mayıs 2009 
Yörede çimento bağlayıcısının kullanımının yaygınlaşması sonucu dış koşullara dayanıklı bir nitelik gösteren bu geleneksel alçı harcının kullanımı ise günümüzde terkedilmiş durumdadır.

Alçı yanında daha eski dönemlere tarihlenebilen ve tahrib olmuş, bazı yapılarda ise kireç bağlayıcılı harç uygulamalar da rastlanmaktadır (Resim-7). Bu kireç harçların üretiminde harcın dayanımını arttırmak ve özeliklerini iyileştirmek için bölgedeki çeşitli toprakların puzolan olarak kullanıldığı da düşünülebilir. Bunun için harçlar üzerinde gerekli analiz çalışmalarına ihtiyaç bulunmaktadır. Bu çalışmada, sadece yöredeki çeşitli toprakların puzolanik özellikleri üzerinde durulmaktadır. Dolayısıyla bu konu ayrı bir çalışmada ele alınabilir.

\subsection{Puzolanlar}

3 yüksek oranda $\mathrm{CaCO}_{3}$ igeren kires taşları pişirildiğind elde edilen ürün \%9s oraninda CaO işeriyorsa bu ürüne yağ̈lı kireş adı verilir. Bu ürün su ile karıştrrıldığinda elde edilen hamur açı havaya birakildiğinda, havadaki $\mathrm{CO}_{2}$ ile birleserek zamanla kalsiyum karbonata $\left(\mathrm{CaCO}_{3}\right)$ dönüşür $\left[\mathrm{Ca}(\mathrm{OH})_{2}+\mathrm{CO}_{2}-\mathrm{CaCO}_{3}+\mathrm{H}_{2} \mathrm{O}\right]$ (Postacioğlu, 1969, 4).
Eski zamanlardan beri volkanik orjinli toprakların kireçle karıştırılarak harç üretiminde kullanıldıkları bilinmektedir. Su içinde bile prizlenebilen ve su etkisiyle dağılmayan dayanıklı harçlar elde edebilmek için yağlı kireçle(3) karıştırılmış bazı doğal ve yapay malzemelerin kullanımı antik çağlara kadar uzanır. Grekler MÖ. 7. yy.'da, günümüzde Santorin toprağı olarak adlandırılan ve sarnıçların iç yüzeylerinde dahi prizlenen bu volkanik malzemelerden yararlanmışlar, Romalılar da Vezüv Yanardağı'nın küllerini özellikle liman, vb. su yapılarında kullanmışlardır. Bu kül, Pouzzoles şehrinin yakınlarından elde edildiği için "Pulvis puteolanus" olarak adlandırılmış (Davidovits, 2000, 1, Rachebourg, 1965, 6) olup bu uygulamanın Etrüskler zamanına kadar gittiği düşünülmektedir. İtalya'da Pouzzoles şehrinin toprağı anlamına gelen Puzzolana
(Pouzzolana) günümüzde dahi volkanik orjinli taşları ifade etmektedir. Santorin adası toprakları, İtalya puzolanları ve Almanların Trası, Amerikalıların tüfleri gibi çeşitli volkanik topraklar harç ve beton üretiminde zaman içinde kullanıla gelmiştir.

Kayseri bölgesi jeolojik açıdan volkanik bir arazi yapısına sahip olduğundan toprakları da aynı bu şekilde puzolanik bir özellik taşımaları kuşku götürmez.

Bununla birlikte bu topraklar üzerinde geniş çaplı bir incelemenin yapılmadı ̆̆ı da dikkati çekmektedir. Sadece Postacıŏ̆lu vd. (Postacıoğlu vd 1960, 56) Kayseri Sivas yolu üzerinde ve Kayseri'ye 30 km. mesafede bulunan ve Ağılmağarası denilen bölgeden aldıkları çeşitli numuneler üzerinde, DIN, ASTM gibi çeşitli standartlara göre yaptıkları deneyler sonucunda bu bölgedeki toprakların puzolanik özelliklere sahip olduklarını saptamışlardır. Ayrıca Postacıoğlu (Postacıoğlu, 1969, 45), Kayseri civarında geniş puzolan yatakları olabileceğini ileri sürmüsstür. Diğer yandan yörede yapı taşı olarak kullanılan İgnimbirit'lerin, yani volkanik tüflerin, bölgedeki bir çimento fabrikasında çimento üretiminde kullanılması, bu taşların da puzolanik özelliğe sahip olduğunun bir göstergesidir.

Puzolanlar, silisyum, alüminyum ve demir mineralleri içeren, kendi başlarına hiçbir bağlayıcılık özelliği olmayan, fakat hidrate kireç ve su karışımı içinde yeni kristaller oluşturarak bağlayıcı ürünler meydana getiren malzemeler olarak tanımlanmıştır. (Rachebourg, 1965,6, Postacioğlu, 1969, 44, Çelik, 2005, 371). ASTM C 618'e göre de kendi kendine bağlayıcılık özelliği çok az olan veya hiç olmayan ancak uygun rutubet şartlarında ve normal ortam sıcaklığında 
kireç ile reaksiyona girdiğinde bağlayıcılık özelliği gösteren ürünler açığa çıkaran, ince toz halindeki silisli veya silisli ve alüminyumlu maddelere puzolan denilmektedir. Bu tür malzemelerle üretilmiş harçların, normal harca göre mekanik ve durabilite özelliklerinin daha üstün olduğu bilinmektedir. Uzun zamandan beri bazı maddelerin hidrate kireçle reaksiyona girerek hidrolik bir karakter taşıyan yeni bileşikler oluşturduğu (Zendri vd, 2004, 1) bilinmektedir. Temelde silisyum, alüminyum ve demir oksitlerden meydana gelen bu malzemeler, volkanik küller, tüfler, boksit gibi doğal olanlar yanında, termik santrallerin baca külleri, yüksek fırın letiyeleri, kalsine edilmiş killerin tozları, yakılmış bazı bitkisel ürünlerin (pirinç, hindistan cevizi kabuğu gibi) külleri gibi yapay maddeler de puzolanik malzeme olarak kullanım alanı bulabilmektedirler. Ayrica feldispat gibi mineraller ve zeolitler de puzolanik özellik gösterebilirler (Melo, vd. 2004, 93). Puzolanlar esasen reaktif silisyum dioksit $\left(\mathrm{SiO}_{2}\right)$ ve alüminyum oksit $\left(\mathrm{Al}_{2} \mathrm{O}_{3}\right)$ 'den oluşmuştur. Geri kalan kısım demir oksit $\left(\mathrm{Fe}_{2} \mathrm{O}_{3}\right)$ ve diğer oksitleri ihtiva eder. Reaktif $\mathrm{SiO}_{2}$ miktarı kütlece $\% 25^{\prime}$ den az olmaması gerekir (Çelik, 2005, 371). Puzolanlar, suyla karıştırıldıklarında çamur haline gelir, Resim: 8-a

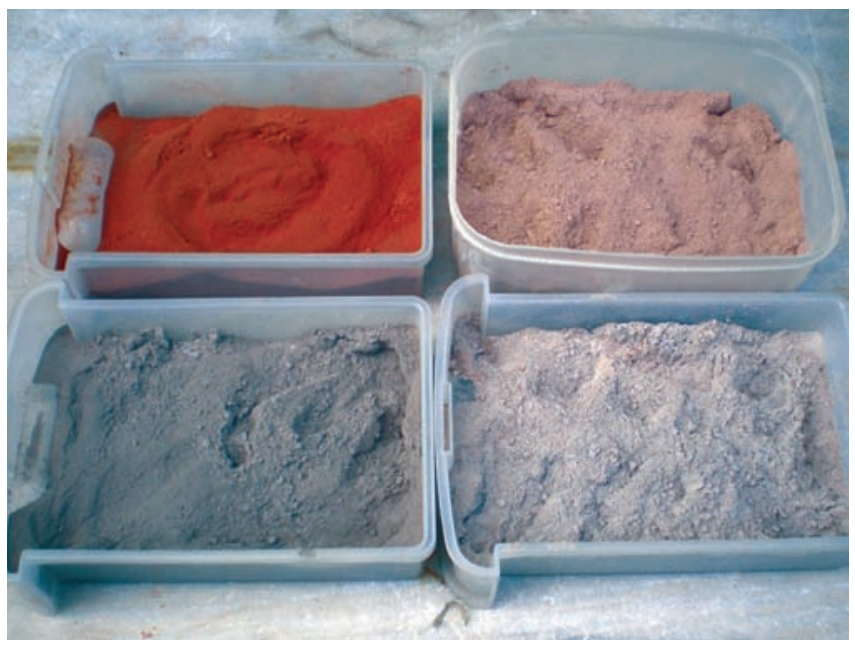

Bu çalışmada, toprakların puzolanik özelliklerini tespit etmek amacıyla toprak katkılı ve kireç bağlayıcılı harç numuneler üretilerek yapılan deneylerle bu harçların mekanik özellikleri incelenmiştir.

\section{2- Ağırnas topraklart ve deneysel çalışma}

\subsection{Kullanulan malzemeler ve mzellikleri}

A ğırnas'ın yerleşim alanının fazla

büyük olmamasına rağmen, toprak çeşitliliği açısından zengin bir yapıda olduğu görülmektedir. Buradaki toprakların fiziksel ve kimyasal özellikleri gibi renkleri de birbirinden farklıdır. Bazı toprak çeşitleri, zamanla ayrışmış gevşek yapıdaki volkanik tüflerden meydana gelmişlerdir. Deneysel çalışmada kullanılmak üzere Ağırnas'ın değişik yerlerinden çeşitli özeliklere sahip dört farklı toprak örneği alınmıştır. Bunlar kırmızı, beyaz, gri ve yöresel olarak kemik toprak şeklinde adlandırılan topraklardır (Resim-8).

Resim: 8-b
Resim: 8-a

Deneysel çalışmada kullanılan toprak örnekleri

Resim: 8- 6

Üretilen numuneler

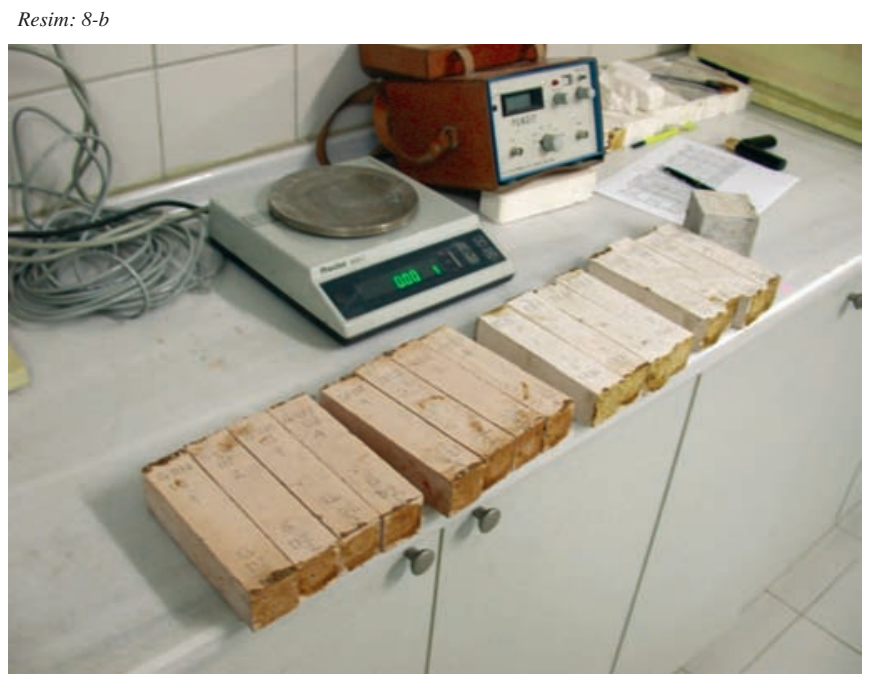




\author{
Resim: 9 Toprakların genel özellikleri ve alınmış \\ Beyaz toprak \\ Resim: 10 \\ Gri Topră̆ın alınmış \\ olduğu Bezirhane
}

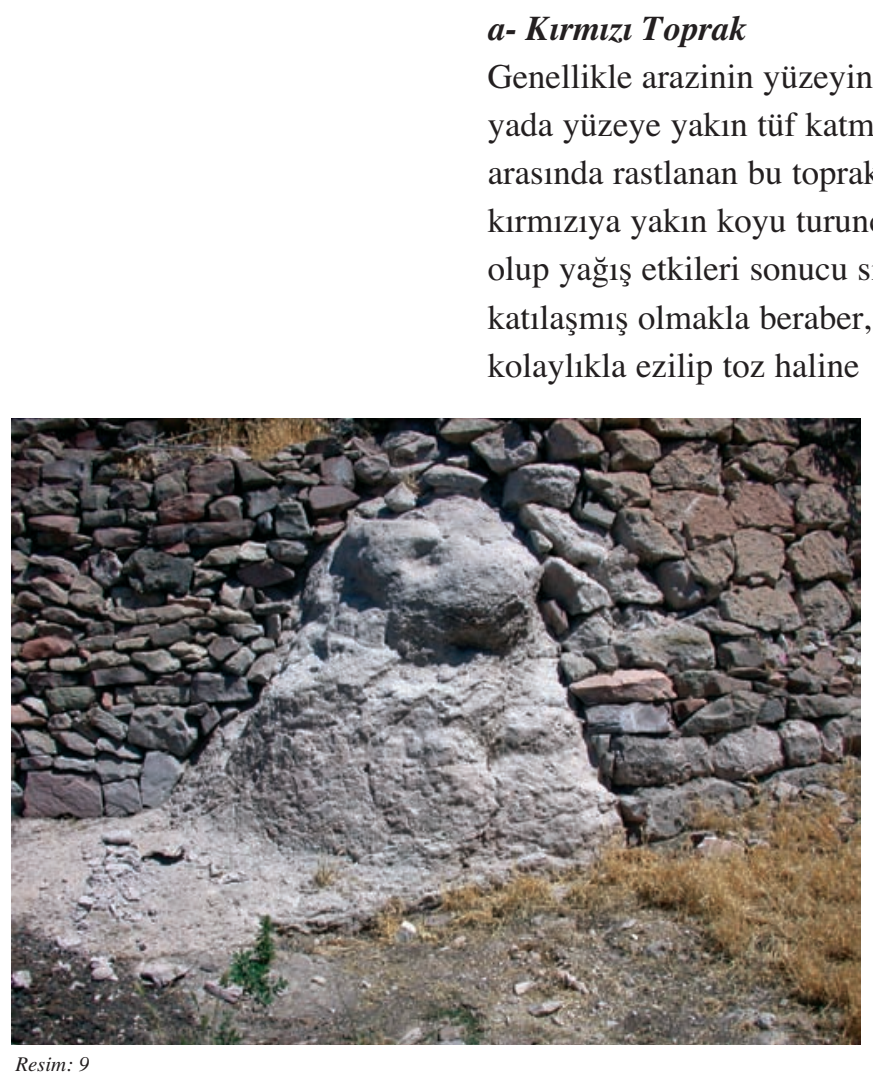

Resim: 9

getirilebilmektedir. Renginden dolayı demir bileşikleri bakımından zengin olduğu tespit edilen bu örnekler tüf katmanlarının arasından alınmıştır.

\section{b-Beyaz Toprak}

Yer yer rastlanan, açık gri renkte olan ve toz halinde bulunan bu toprakların volkanik tüflerin zamanla ayrışması sonucu oluştuğu anlaşılmaktadır. Çünkü bu toprağın bulunduğu yerlerde aynı renkte ve özellikte bloklar halinde, yapı taşı olarak kullanılmaya elverişli olmayan gevşek yapıda volkanik tüflere de rastlanmaktadır. Kolaylıkla ezilme ve toz haline getirilebilme özelliğine sahiptirler (Resim-9).

\section{c- Yeralt Bezirhane Toprağı (Gri toprak)}

Ağırnas'ta çok sayıda yeraltı mağaraları ve buralarda oluşturulmuş bezirhaneler mevcuttur. Onaltıncı yüzyıldan beri beziryağ 28 bezirhane olduğu Osmanlı kayıtlarında yer almaktadır. Günümüzde bunlardan ancak on tanesi tesbit edilebilmiştir (Ağırnas, 2002,10). Çeşitli atmosfer ve yağış etkilerinden korunduğu ve niteliğini muhafaza ettiği düşünülerek yaklaşık

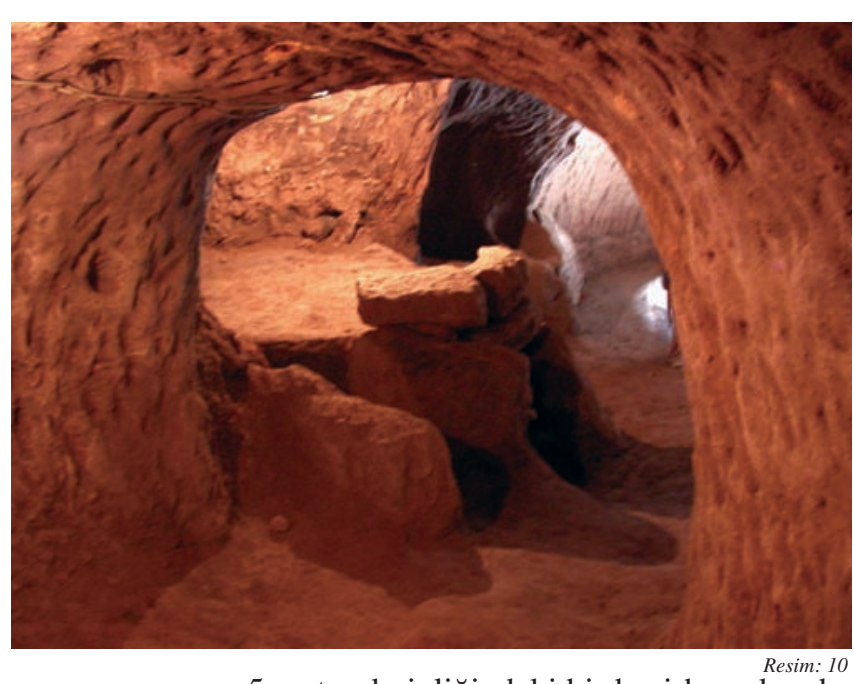

5 metre derinliğindeki bir bezirhaneden de toprak numuneleri alınmıştır. Nemli halde koyu gri renkte olan bu toprak, kuruduğu zaman rengi açılmakta olup kolaylıkla toz haline getirilebilmektedir. (Resim-10)

\section{d-Kemik (Gebik) toprak}

\section{(Turuncu, krem toprak)}

Taş ocaklarında, tüflerin üzerinde çeşitli kalınlıklarda bulunan krem ve turuncu renklerdeki toprağa yörede "Kemik" yada "Gebik Topră̆gl" adı verilmektedir. (Resim-11) Bol miktarda bulunan, çoğunlukla da krem renginde olan ve killi bir özellik taşıyan bu toprak su ile temas ettiğinde plastik bir özellik kazanmakta ve kohezyon özelliği gösterebilmektedir. Genellikle evlerin damlarına 40-70 cm. 


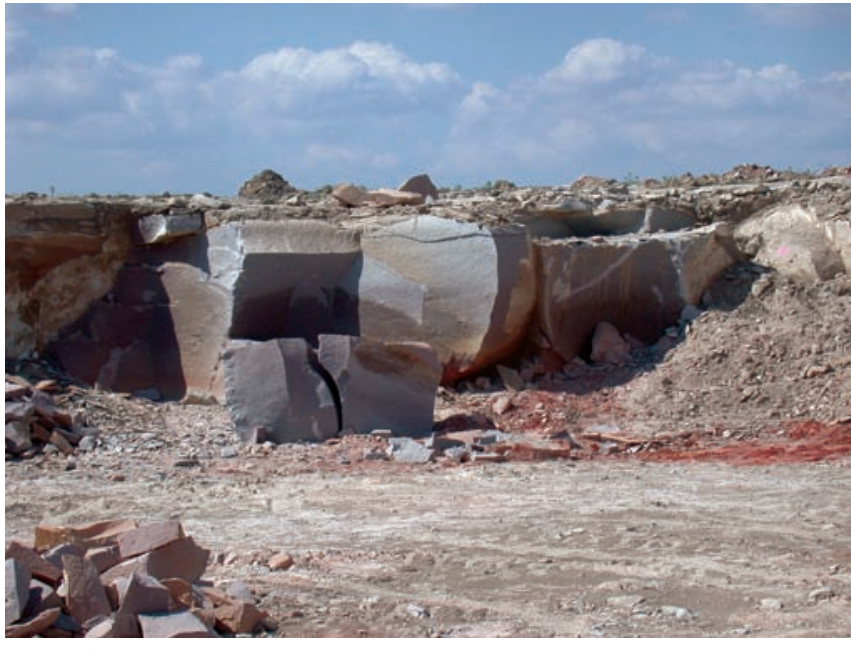

Resim: 11

kalınlığında bir tabaka halinde serilen Gebik toprak $\mathrm{lo}_{4}$ taşı ile sıkıştırıldığında bu özelliğinden dolayı geçirimsiz bir hal almakta, dolayısıyla yağmur ve kar suyunun iç mekanlara geçişini engellemektedir(Resim-12). Bu toprağın geçirimsizlik özelliğine sahip olması içeriğinde kil minerallerinin varlığ 1 ile de ilișkili olabilir.

\subsection{Analizler ve deney yöntemi}

Toprakların özelliklerini belirlemek amacıyla ilgili standartlar doğrultusunca kimyasal, fiziksel ve granülometrik analizler yapılmıştır.

\subsubsection{Kimyasal analizler}

Kimyasal bileşimlerini tespit etmek için 0,200 gr ve 125 mikron elek altı incelikteki örneklere lityum metaborat-lityum tetraborat $\left(\mathrm{LiBO}_{2}-\mathrm{LiB}_{4} \mathrm{O}_{7}\right)$ füzyonu ile çözünürleştirilmiş ve İndüktif Eşleşmiş Plazma Emisyon Spektroskopisi (Inductively Coupled Plasma Emission Spectroscopy, ICP-ES) ve İndüktif Eşleşmiş Plazma Kütle Spektroskopisi (Inductively Coupled Plasma Mass Spectroscopy, ICP-MS) ile analizler yapılmıștır.

ACME Analyical Laboratoires Ltd.'nde (Kanada) tarafından yapılan ICP analizi ile gösterilmiştir.

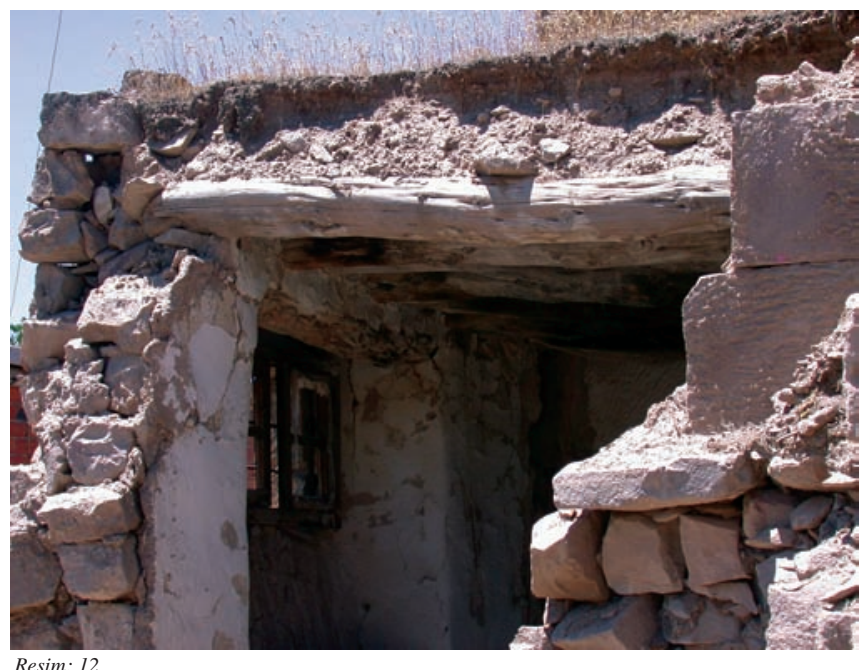

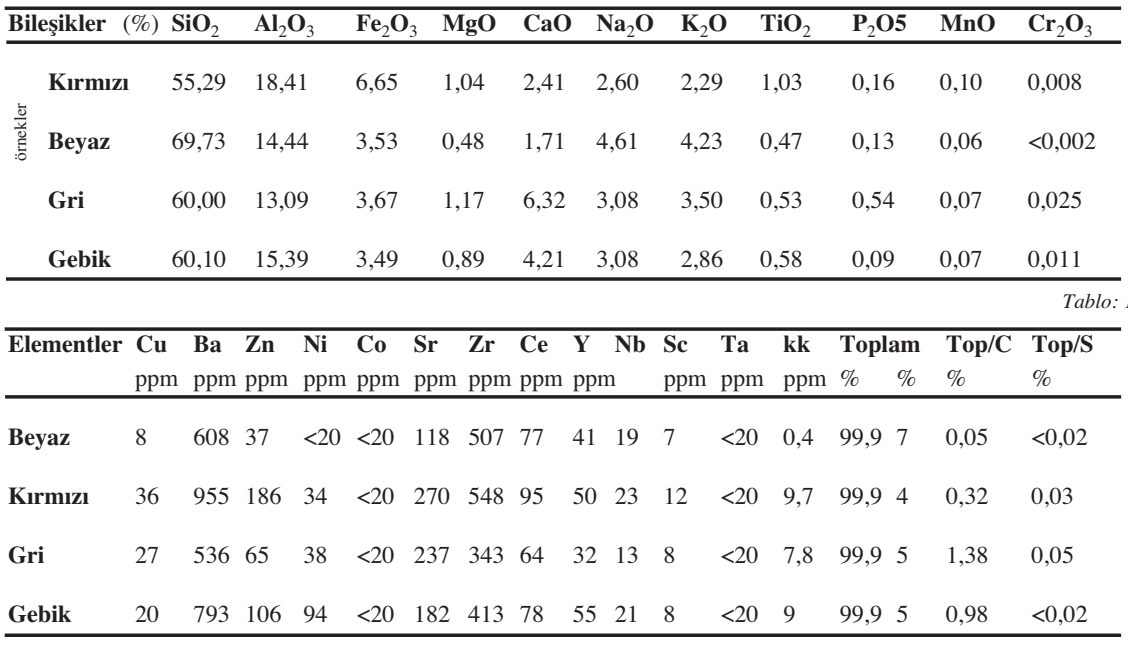

örneklerin genel kimyasal içerikleri metal oksit (\%) olarak, içeriklerinde bulunan diğer eser miktardaki

Resim: II Tablo: 2

Kemik toprağın alındı̆̆ı

taş ocă̆ı

Resim: 12

maddelerde element (ppm) olarak tespit edilmiş ve sonuçlar Tablo-1 ve

Dam üzerine serilen

kemik toprak

Tablo: I

Tablo-2'de gösterilmiştir.

Karışımlarda bağlayıcı olarak

kullanılan bağlayıcı kireç ise

Entegre Lafarge tesislerinden elde edilmiş olup kimyasal ve fiziksel özellikleri Tablo-3'de verilmektedir. Standard kum kullanılarak TS 25'e göre hazırlanan karışımlarda gerekli malzeme miktarlarının tespit edilmesi için esas alınan yöntem de Tablo-4'de
Toprak örneklerinin oksit bileşik içerikleri

Tablo: 2

Topraklarin iz element iferikleri, toplamdaki karbon (C)ve kükürt (S) miktarları

4 Kemik yada Gebik toprak örtüsünü zaman zaman sıkıstırmak için kullanılan silindir şeklinde yapılmış taşa verilen isim. Taş silindirin boyu 70-100, sapı ise $25-40$ $\mathrm{cm}$. ler arasında değisebilmektedir. Bu silindirin yanal yüzeylerine, dam üzerinde hareketini sağlamak ve cekmek üzere demir yada iplerin geçirildiǧi oyuklar açılmıs olup genellikle tüflerden yapılmıştır. Eski tas evlerin damlarının bir köșesinde bu taştan muhakkak bir tane bulunmaktadir. 


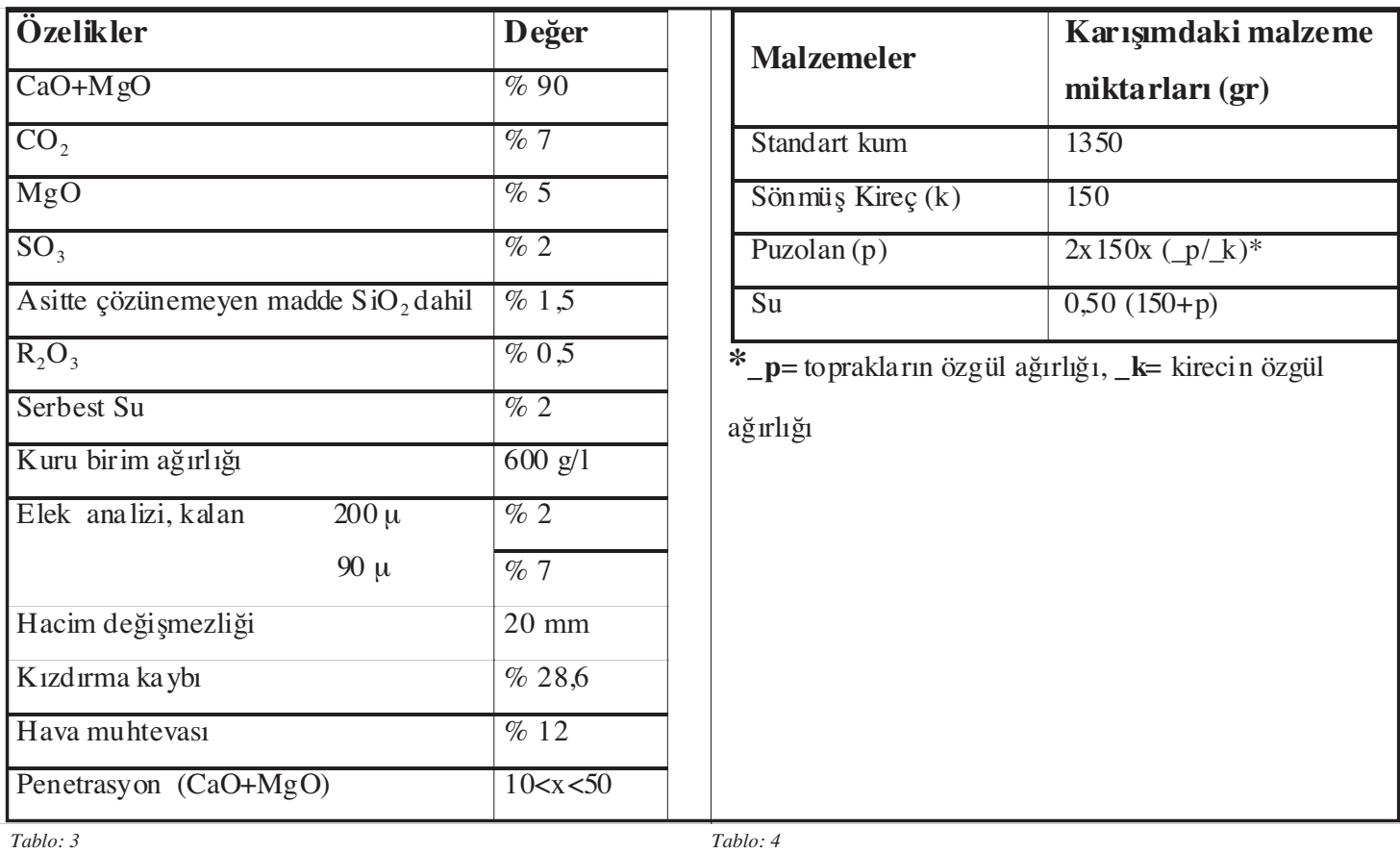

\subsubsection{Fiziksel analizler}

Topraklar üzerinde TS 639'da belirtilen

Le Chatelier balonu ile yapılan özgül ağırlık ve $1050{ }^{\circ} \mathrm{C}$ 'de yapılan kalsinasyon sonucu elde edilen kızdırma kaybı değerleri de Tablo-5'de gösterilmektedir. TS 639'daki ilgili deney uygulandığında-

\begin{tabular}{lllll}
\hline \multirow{2}{*}{ örnekler } & nem & k1zdırma kaybi & özgül kütle (_) & 45 m'luk elekte \\
& $(\%)$ & $(\%)$ & $(\mathrm{g} / \mathrm{cm} 3)$ & kalan $(\%)$ \\
\hline HK & 6,38 & 9,7 & 2,24 & 36,9 \\
HB & 4,77 & 0,4 & 2,41 & 9,3 \\
HG & 7,31 & 7,8 & 2,29 & 19,2 \\
HT & 5,95 & 9,0 & 2,35 & 25,7 \\
& & & & \\
\hline Tablo: 5 & & &
\end{tabular}

Tablo:3 puzolan malzemenin en çok \% 5,0

Kirecin kimyasal ve kızdırma kaybı değerine sahip olması fiziksel özellikleri

Tablo: 4

TS $25^{\prime}$ e göre hars üretiminde gerekli malzeme miktarlarının tespit yöntem

Tablo: 5

Topraklarin fiziksel özellikleri

şekil: I Topraklarin granülometrik özellikleri öngörülmüştür. Bu koşulu sadece beyaz renkli toprak örneği sağlamakta olup, diğer örneklerin kızdırma kaybı değerleri ise daha yüksek elde edilmiştir.

ASTM C 618-03 standardına göre ise [N] sinıfını oluşturan bu tür puzolanlarda kızdırma kaybı oranı en çok \% 10 şeklinde öngörülmüştür. Dolayısıyla bu standart esas alınacak olursa elde edilen değerlerin öngörülen sınırlar içerisinde olduğu söylenebilir.

\subsubsection{Granülometri analizleri}

$105^{\circ} \mathrm{C}^{\prime} \mathrm{de}( \pm 2)$ kurutulan tüm toprak örnekler üzerinde granülometri analizleri yapılmıştır. Analiz sonucunda belirlenen tane dağılımları ve granülometri eğrileri Şekil-1'de gösterilmektedir.

Şekil-1'de beyaz ve gri renkli toprağının incelik ve granülometrik dağılım açısından daha uygun özelliklere sahip olduğu,

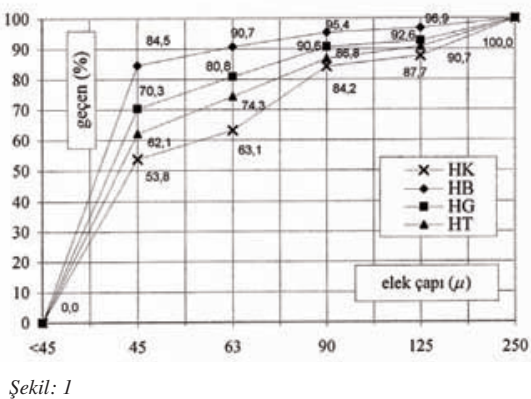

kırmızı ve turuncu renkli toprağın ise nispeten daha iri tanelerden oluştuğu görülmektedir. ASTM C 61803 standardında 45 m'lik elek üzerinde en çok \% 34 kalıntı kalması öngörülmüştür. Kırmızı toprak dışındaki tüm örnekler bu koşulu sağlamaktadırlar (Tablo-4). Kırmızı 
toprak örneğinde bu oran \% 36,9 şeklinde biraz yüksek elde edilmiş olmakla birlikte bunun standart değere yakın olduğu da söylenebilir.

\subsection{Puzolanik aktivite deneyi ve deney yöntemi}

Topraklar üzerinde aktivite deneyleri için üretilen numuneler TS-25'de belirtilen Rilem-Cemboreau metoduna göre 40 x 40 x $160 \mathrm{~mm}$. boyutlarındaki standart çelik kalıplarda üretilmiştir. Numuneler hazırlandıktan sonra kalıpların üzeri standardın önerdiği şekilde buharlaşmayı önleyecek şekilde kapatılarak 24 saat laboratuar koşullarında bekletilmiş ve sonra $55 \pm 2{ }^{\circ} \mathrm{C}$ sabit sicaklıkta etüv içerisinde 6 gün küre tabi tutulmuşlardır. Numuneler etüvden alındıktan ve 4 saat dinlendirildikten sonra ultrases hız ölçümleri yapılarak buradan hareketle dinamik elastiklik modülleri saptanmış ve daha sonra da mekanik testlere tabi tutulmuşlardır. Ultrases hızı ölçümleri TS EN 14579 Standardından hareketle PUNDİT markalı ölçüm cihazında, basınç, eğilme ve yarmada çekme gibi temel mekanik deneyler ise, 60-600 $\mathrm{N}$ kapasiteli AMSLER marka üniversal preste _ yükleme hızında gerçekleştirilmiştir. Toplam 5 seri ve 15 adet numune üretilmiştir. Numunelerin kodlaması ise şu şekildedir:

HR - Referans harç (hiçbir katkı içermeyen kireç harcı)

HK - Kırmızı topraklı kireç harcı

HB - Beyaz topraklı kireç harcı

HG - Gri topraklı kireç harcı (Bezirhane toprağı)

HT - Turuncu-krem toprakl1 (Gebik) kireç harcı

Hazırlanan kireç harçları üzerinde

\begin{tabular}{|c|c|c|c|c|c|c|c|}
\hline \multirow[b]{2}{*}{ Seriler } & \multirow{2}{*}{$\begin{array}{l}\Delta \\
(\mathrm{g} / \mathrm{cm} 3)\end{array}$} & \multirow{2}{*}{$\begin{array}{l}\text { ultrases hizı } \\
\mathrm{V}(\mathrm{km} / \mathrm{sn})\end{array}$} & \multicolumn{2}{|c|}{ dinamik eğilme } & \multirow{2}{*}{$\begin{array}{l}\begin{array}{l}\text { basınç } \\
\text { gerilmesi }\end{array} \\
(\mathrm{N} / \mathrm{mm} 2)\end{array}$} & \multirow{2}{*}{$\begin{array}{l}\text { yarmada çekme } \\
\text { gerilmesi } \\
(\mathrm{N} / \mathrm{mm} 2)\end{array}$} & \multirow{2}{*}{$\begin{array}{l}\text { aktivite } \\
\text { Indisi * } \\
(\%)\end{array}$} \\
\hline & & & $(\mathrm{kN} / \mathrm{mm} 2)$ & $(\mathrm{N} / \mathrm{mm} 2)$ & & & \\
\hline$\overline{\mathrm{HR}}$ & 1,77 & 1,7 & 5,2 & $\overline{0,9}$ & 1,3 & $\overline{0,7}$ & $\overline{---}$ \\
\hline HK & 1,91 & 2,5 & 12,0 & 1,3 & 4,3 & 1,5 & 107 \\
\hline HB & 1,96 & 2,9 & 17,1 & 2,2 & 5,9 & 2,3 & 147 \\
\hline HG & 1,94 & 2,6 & 13,2 & 1,7 & 4,5 & 2,0 & 112 \\
\hline HT & 1,94 & 2,7 & 15,1 & 1,8 & 4,7 & 2,2 & 117 \\
\hline
\end{tabular}

Puzolanik indis=Ra/Rb 100 bağıntıslyla hesaplanmaktadır. (Ra=puzolan katkılı örneklerin basınç dayanımı, Rb=puzolan içermeyen örneklerin basınç dayanımı, burada TS-25 değeri referans alınmuştır)

yapılan ultrases hız ölçümleri, Tablo: 6 Tablo:6 dinamik E-Modülleri ve puzolanik Üretilen harc numunelerden aktivite deneyi sonucunda elde elde edilen toplu sonuçlar edilen veriler topluca Tablo-6'de

gösterilmektedir.

\section{3- Deney sonuçlarının srdelenmesi ve sartışmalar}

\subsection{Kimyasal analizler sonuçlart}

Yapılan ICP analizlerinde toprakların genel kimyasal kompozisyonu Tablo-1 ve Tablo-2'de gösterilmiştir. Kimyasal analiz sonucunda topraklardaki $\mathrm{CaO}$ oranı en fazla Gri toprakta elde edilmiştir. Diğer örnekler ise daha az kireç içermektedir. Tüm toprakların $\mathrm{MgO}$ oranı içerikleri ise daha az miktardadır. Kırmızı toprağın sahip olduğu renk, içeriğindeki Fe2O3 miktarının fazla olmasından ileri gelmektedir. Diğer örneklerde ise bu bileşiğin oranı daha azdır. ASTM C 618-03 ve TS 25'e göre puzolanik aktivite deneyinde kullanılacak maddenin içeriğindeki $\mathrm{SiO}_{2}, \mathrm{Al}_{2} \mathrm{O}_{3}$ ve $\mathrm{Fe}_{2} \mathrm{O}_{3}$ oranı toplamlarının en az \% 70, $\mathrm{MgO}$ oranı ise en çok \% 5,0 olması istenmektedir.

Kimyasal analiz sonuçlarından da görüldüğü üzere çalışmada kullanılan tüm toprak örnekler bu koşulu sağlamaktadır. Analiz sonucunda Beyaz renkli toprak örneğinde bu bileşiklerin toplam oranının $\%$ 87,7 şeklinde en yüksek değere sahip olduğu tespit edilmiştir. 
Topraklardaki Ba ve Sr gibi iz element konsantrasyonları genellikle birbirine benzemekte ve yüksek değerler almaktadırlar. Volkanik kökenli taş ve topraklar genellikle bu elementler bakımından zengin bir yapıya sahiptir (Sanchez-Moral vd, 2005, 1558). Bu durum, toplam oksit bileşikleri yanında, iz element içerikleri bakımından da toprakların volkanik orjinli oldukların göstermektedir.

\subsection{Harçların ultrases hızı ve E-Modülü açısından değerlendirilmesi}

Toprak katkılı ve katkısız harç örneklerin mekanik deneyler öncesi tespit edilen ultrases hızları ve dinamik E-Modülü değerleri Şekil-2 ve Şekil-3'de gösterilmiştir.
E-Modüllerinde de izlenmektedir (Şekil-2). E-Modüllerindeki artış oranları HK serisinde \% 130, HB serisinde \% 226, HG serisinde \% 152 ve HT serisinde de $\% 187$ şeklindedir. Bu durum volkanik toprakların içerdikleri aktif silis bileşiklerinin kalsiyum hidroksitle $\left[\mathrm{Ca}(\mathrm{OH})_{2}\right]$ kimyasal reaksiyona girmeleri sonucu silikat bir yapı oluşturduklarını göstermektedir. Beyaz toprağın daha yüksek değerlere sahip olması aktif silis içeriğinin diğer topraklara göre fazla olmasından ve serbest kireçle daha iyi bir silikatlaşma oluşturmasından ileri geldiğinin göstergesidir. Aynı zamanda granülometrik özellikten dolayı doldurma etkisinin de burada rolü olmaktadır. $\mathrm{Bu}$ durum harcın E-Modülünü ve ses hızlarını da arttırmaktadır. Silikatlaşmanın mekanizması kısaca şu şekilde açıklanabilir.

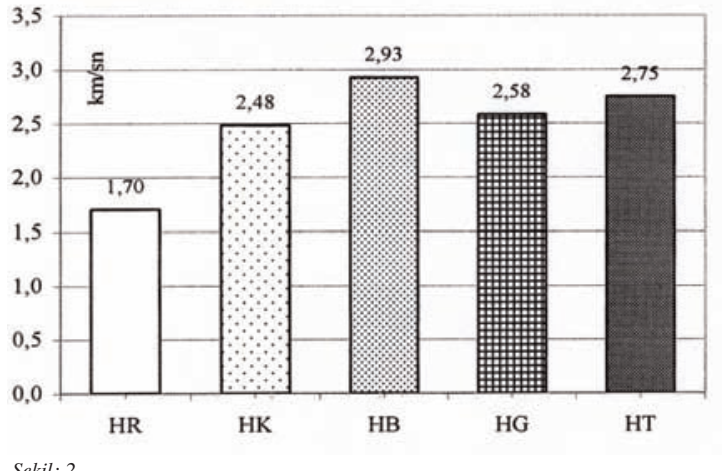

Şekil-2'de beyaz toprak katkılı harçların ses hızlarının diğer karışımlara göre daha yüksek olduğu görülmektedir. Ses geçiş hızları katkısız kireç harcına göre kırmızı topraklı karışımda (HK) \% 46, beyaz topraklı karışımda (HB) \% 72 gri toprak karışımda (HG) \% 52 ve turuncu toprak karışımda (HT) ise \% 61 oranında bir artış sağladığı saptanmıştır. Burada, harçların puzolanik özelliği ile ultrases hızları

şekil: 2 arasında lineer ilişkilerin olduğu ve Harç karısıımlarının ultrases hizlari

şekil: 3

Karısımların dinamik E-Modülleri puzolanik malzeme ile üretilmiş kireç harçlarının ultrases hızlarının da yüksek değerler aldığı görülmektedir. Benzer davranış harçların dinamik

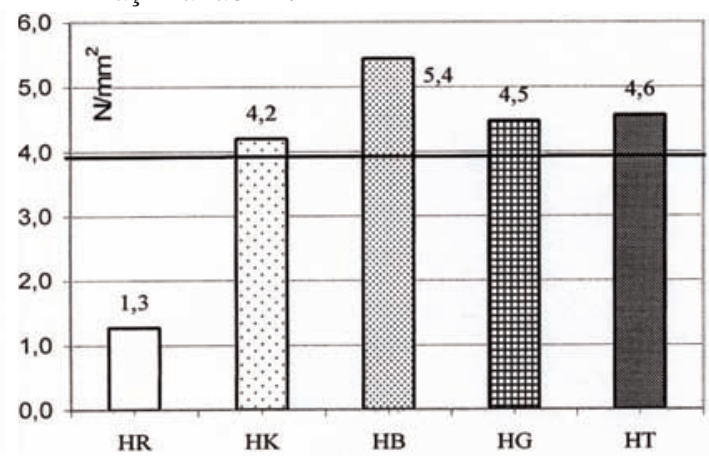

Sekil: 3

Karışımda kirecin etkisi nedeniyle kalsiyum açısından doygun ve bazik ortam oluşmakta ve bu kimyasal şartlar, puzolanın puzolanik reaksiyona girmesi için uygun koşulları oluşturmaktadır. Burada mineraller kısmen erimekte ve onları oluşturan silis ve alümin serbest kalmaktadır. Bu mineraller daha sonra kalsiyum ve hidroksil iyonlariyla, kalsiyum hidratları (C-S-H ve C-A-H) meydana getirmek için reaksiyonlara girmektedirler (Cabane, 2004, 172). Zamanla bağlayıcının mekanik özeliklerinde gözlenen artışlar bu hidratların etkisini açıklamaktadır. 
Puzolanların serbest kireçle birleşmesinde en önemli rol aktif $\mathrm{SiO}_{2}$ tarafindan oynanmaktadır. Yapılan araştırmalar kristal silisin kireçle birleşmediğini göstermektedir. Bu bakımdan bir puzolanda kolloidal silis veya bir başka ifadeyle aktif silis ne kadar fazla ise, o puzolan o oranda yüksek bir bağlayıcılık özeliğine sahiptir. Aktif $\mathrm{SiO}_{2}$ 'in belirli bir değerden düşük olması ve böyle bir maddenin kireçle karıştırılarak kullanılması ise beklenen yararı sağlamaz. Bunun yanında bir puzolanda $\mathrm{SiO}_{2}$ miktarının fazla bulunması, aktif silisin yeter miktarda bulunma ihtimalini arttırması dolayısıyla, önemli bir işaret ise de, hiçbir zaman o maddenin puzolanik özelliğe sahip olduğunu kesin olarak göstermez (Postacıŏ̆lu vd., 1960, 34). Örneğin kuvars mineralleri puzolanik aktiviteye sahip değildir (Böke vd., 2004, 92). Bu bakımdan bir maddenin puzolan olup olmadığını anlamak için en basit yol, doğrudan doğruya mekanik deneylere (basınç ve çekme dayanımlarının saptanması y öntemine) başvurmaktan ibarettir (Postacıoğlu vd., 1960, 34).

\subsection{Harçların mekanik özellikler açısından değerlendirilmesi}

Puzolan katıldığı zaman bağlayıcının mekanik dayanımında bir artış beklenir. Tablo-5'te gösterilmiş basınç ve eğilme gerilmesi değerlerine göre tüm karışımların TS 25'in öngördüğü aktivite için gerekli, min. $4 \mathrm{~N} / \mathrm{mm}_{2}$ basınç ve $1 \mathrm{~N} / \mathrm{mm}_{2}$ eğilme gerilmesi değerlerini sağlamaktadır. Ayrıca hiçbir toprak katkısı içermeyen bir seri kireç harcı da (HR) üretilmiş ve aynı kür koşullarına maruz bırakılarak toprak katkılı karışımlarla bir mukayesesi de yapılmıştır. Bu değerlendirmelerin sonucuna göre de tüm karışımların katkısız kireç harcına kıyasla daha iyi sonuçlar verdiği tespit edilmiştir.
Örnekler üzerinde yapılan basınç, eğilme ve yarmada çekme deneyleri sonucunda elde edilen veriler karşılaştırmalı olarak Şekil-4 ve Şekil-5' de gösterilmektedir. Burada, mekanik deneylerden elde edilen sonuçlarla, ultrases hızı ve E-Modülü değerlerinin paralel bir davranış içinde oldukları da görülmektedir.

$\mathrm{Bu}$ sonuçlara göre standardın (TS 25) öngördüğü $>4,0 \mathrm{~N} / \mathrm{mm}_{2}$ basınç gerilmesi değerini tüm katkılı numuneler sağlamaktadırlar. Öngörülen bu değere göre basınç

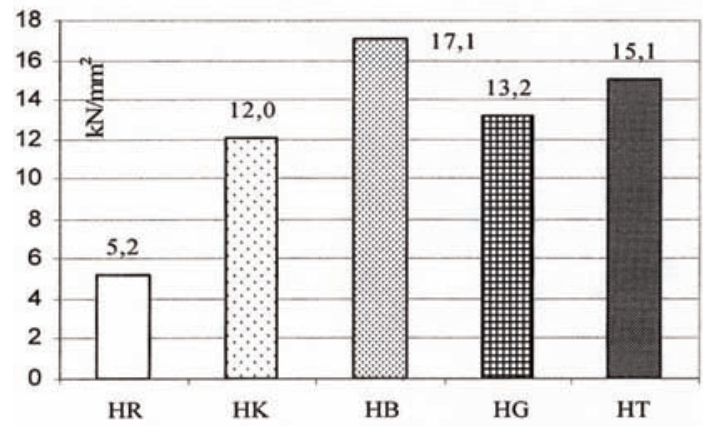

Şekil: 4

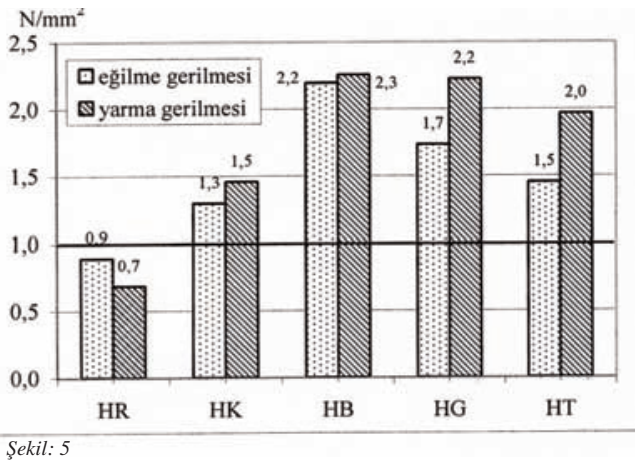

gerilmelerinde $\mathrm{HK}$ serisinin \% 8,

$\mathrm{HB}$ serisinin \% 46, HG serisinin, \% 12 ve HT serisinin ise \% 18 oranında artışlar gösterdikleri tespit edilmiştir. Ayrıca bu oranlar katkısız kireç harcıyla karşılaştırıldığında daha fazla değerler almaktadirlar $(\mathrm{HK}=\% 239, \mathrm{HB}=\% 360$, $\mathrm{HG}=\% 252$ ve $\mathrm{HT}=\%$ 272). Aynı davranış eğilme ve yarmada çekme değerlerinde de söz konusudur. TS $25^{\prime}$ 'in öngördüğü referans $>1,0 \mathrm{~N} / \mathrm{mm}_{2}$ değerine göre eğilme gerilmelerindeki artış oranları $\mathrm{HK}$ serisinde \% 30, HB serisinde \%
Şekil: 4

Harf̧larin basinf gerilmelerinin (puzolanik aktivitelerinin) karşılaştırması

şekil: 5 Harçların eğilme ve yarmada cekme gerilmelerinin karşılaştırılması 
120, HG serisinde, \% 70, ve HT serisinde ise $\% 80$ şeklindedir. Yarma gerilmelerinde ise bu değerler katkısız harca göre HK serisinde \% 113, HB serisinde \% 272, HG serisinde, $\% 195$, ve HT serisinde ise \% 227 olarak elde edilmiştir. $\mathrm{Bu}$ değerler katkısız kireç harcı referans olarak alındığında ise basınç gerilmelerinde olduğu gibi daha yüksek değerlere ulaşmaktadır. Örneğin, HK serisinde eğilme gerilmesindeki artış oranı $\%$ 46, HB serisinde \% 146, HT serisinde ise \% 106 şeklindedir. Bu verilere göre HB serisi puzolanik aktivitesi ve puzolanik aktivite indisi en yüksek olan gurubu oluşturmaktadır (Tablo-6, Şekil-5). Belirtildiği gibi puzolan bir malzeme harca katıldığı zaman mekanik dayanımlarda iyileşmeler beklenir. Dolayısıyla bu sonuçlardan açıkça görülüyor ki, toprakların ilave edilmesi kireç harcının mekanik dayanımını artırmaktadır.

Bilindiği gibi sönmemiş kireç su ile reaksiyona girdiğinde sönmüş kirece (kalsiyum hidroksit $\mathrm{Ca}(\mathrm{OH}) \mathrm{O}_{2}$ ) dönüşür.

Puzolanlar, oluşan bu serbest kireçle reaksiyon girerek kalsiyum ve alümina silikat kristalleri oluştururlar (Zendri vd., 2004,1, Cerny vd, 2006,850). Puzolan - kireç reaksiyonu şu şekilde ifade edilebilir;

$\mathrm{CaO}>\mathrm{H}_{2} \mathrm{O}>\mathrm{Ca}(\mathrm{OH})_{2}$

$\mathrm{Ca}(\mathrm{OH})_{2}+$ puzolan $+\mathrm{H} 2 \mathrm{O}>\mathrm{CSH}+\mathrm{CASH}$ (hidrate

kalsiyum alümina silikat)

$\mathrm{CaSiO}_{3} \cdot \mathrm{H}_{2} \mathrm{O}+\mathrm{CaAlO}_{3} \mathrm{O}_{3}$

Puzolanın $\mathrm{Ca}(\mathrm{OH})_{2}$ ile reaksiyonu sonucu oluşan silikat sistemi harcın kısa sürede prizlenmesini sağlamakta, prizlenme reaksiyonu için $\mathrm{CO}_{2}$ 'e ihtiyaç duyulmadığ için su içinde veya nemli ortamda bile prizlenme gerçekleşebilmektedir. Dolayısıyla puzolanlar bağlayıcının ve harcin mekanik mukavemetini arttırmakta, su etkilerine karşı dayanıklı olmalarını sağlamaktadır. Puzolandaki amorf silis, küçük boyutlu ve yüzey alanı fazla olduğu için hidrate kireçle $\left(\mathrm{Ca}(\mathrm{OH})_{2}\right)$ daha fazla bir reaktif olma niteliği taşır. Burada bir asit-baz reaksiyonu söz konusudur. Silis zayıf bir asittir ve kuvvetli bir baz olan kireç, volkanik puzolan tozları ile asit-baz reaksiyonuna girince iç yapıda yukarıda belirtilen kalsiyum silikat ve alüminat kristal sistemleri oluşur. Yapılan bir çalışmada (Baronio vd., 1997, 76) yapay bir puzolanla hidrate kireç ve su arasındaki reaksiyonlar incelenmiş ve hidrate tetrakalsiyum alüminat $\left(\mathrm{C}_{4} \mathrm{AH}_{13}\right)$, hidrate trikalsiyum alüminat, $\left(\mathrm{C}_{3} \mathrm{AH}_{6}\right)$ hidrate kalsiyum alüminat (CSH) ve hidrate gehlenit $\left(\mathrm{C}_{2} \mathrm{ASH}_{8}\right)$ bileşikleri oluştuğu gözlenmiş ve bunun kireç tarafından oluşturulmuş bazik ortamda kolaylaştığ 1 tesbit edilmiştir. Meydana gelen bu yapı ise harcın mekanik özelliklerini kısa sürede kazanmasını sağlamaktadır.

Bu çalışmada, toprakların puzolanik aktivitelerinin mekanik yolla belirlenmesi yöntemi esas alınmıştır. Bir maddenin puzolanik özelliğini saptamak için termal, fiziksel ve kimyasal gibi değişik yöntemler de bulunmaktadır (Shi, 2001, 778). Puzolanik aktivitenin kimyasal yolla belirlenmesi çalışmalarından biri de Chapelle test metodu olarak bilinen ve temeli aslında Vicat'a kadar uzanan yöntemdir. Bu, bir kireç çözeltisiyle belirli bir miktardaki puzolan maddesinin belirli bir süre muamele edilmesi ve $\mathrm{Ca}(\mathrm{OH})_{2}$ ile puzolanın reaksiyona girmesi sonucu oluşan bileşiklerin belirlenmesi esasına dayanmaktadır (Bich, 2005, 152 ve Bénoît, 1967). Bu yöntem $\mathrm{Ca}(\mathrm{OH})_{2}$ ile reaksiyona girebilecek puzolan miktarını ve puzolanik aktivitenin oluşumunu saptamak açısından 
yararlı bir metod olmakla birlikte, malzemenin mekanik dayanımını önceden kesin olarak öngörmek için her zaman yeterli değildir (Ambroise vd., 1987, 62). Ayrıca puzolanın kimyasal bileşiminin bilinmesi ve özellikle aktif $\mathrm{SiO}_{2}$ miktarının tayin edilmesi; malzemenin mukayesesi, atıl maddelerin miktarını göstermesi ve puzolanın orijini hakkında fikir vermesi bakımından önemlidir. Bununla birlikte, kimyasal bileşim bir maddenin puzolan olma ihtimalini açıklar, fakat bu maddenin puzolanik özelliğe sahip olduğunu kesin bir şekilde ifade etmez (Postacıoğlu vd., 1960, 42). Bu bakımdan puzolanik durumun anlaşılması için puzolanlar üzerinde muhakkak mekanik deneylerin yapılması gereği de bulunmaktadır.

\section{4- Sonuçlar ve genel değerlendirmeler}

Yapılan bu deneysel çalışmadan elde edilen verilere göre, gerek yeraltından gerek yer üstünden alınan tüm toprak örneklerinin çeşitli oranlarda puzolanik özelliklere sahip oldukları ve aktivitesi en yüksek toprak örneğinin ise beyaz renkli toprak olduğu tespit edilmiştir. Gri ve turuncu toprakların özellikleri ise genelde birbirine benzer niteliktedir. Mekanik değerleri diğer örneklere göre kısmen daha düşük olan ise kırmızı renkli toprak örneği olmuştur. $\mathrm{Bu}$ durum, kırmızı toprak içerisinde $\mathrm{Ca}(\mathrm{OH})_{2}$ ile reaksiyona girebilecek yeter miktardaki amorf bileşiklerin diğerlerine göre kısmen daha az olduğunu, bununla birlikte belirli bir aktiviteye de sahip bulunduğunu göstermektedir. Kimyasal analiz sonuçları da bunu desteklemektedir. Ayrica granülometri analiz verileri de bu toprağın diğerlerine göre nispeten daha iri taneli olduğunu göstermektedir ki, bilindiği gibi incelik, puzolanik aktivite üzerinde etkili olan kriterlerden birini oluşturmaktadır. Tüm topraklarda çeşitli oranlarda puzolanik özellikler tespit edilmiş olması bunların volkanik orjinli olduklarını ifade etmektedir . Yurdumuzun değişik bölgelerindeki tarihi yapılarımızın hidrolik özelliğe sahip harç ve sıvalarının üretiminde tuğla kırığı ve tozları gibi yapay puzolanlar kullanıldığı gibi volkanik orjinli topraklar da puzolan olarak kullanılmış olabilirler. Dolayısıyla tarihi eserlerin ve yapıların bulundukları bölgelerdeki toprakların gerekli incelemeleri yapılarak puzolanik özelikleri tespit edilmelidir. Bunun yanında ayrıca o bölgelerin tarihi yapılarında kullanılmış olan harçların özelliklerinin araştırılması da gerekir. Sonuçta bu araştırmalar, onarım çalışmalarında kullanılacak yeni malzemelerin üretiminde birer referans teşkil edebilecektir. Diğer yandan bölgedeki alçı taşlarının ve bu taşların pişirilmesiyle üretilmiş alçıyla yapılan geleneksel alçı harçlarının özellikleri de incelenmelidir. Bu saptamalar terk edilmeye yüz tutmuş geleneksel teknolojilerin tekrar canlanması ve uygulama imkanı bulmasını sağlayacaktır. Bu çalışmalar diğer yandan yörenin özgün mimari dokusunun korunması açısından uygun malzemelerin seçim ve üretimi bakımından da ayrı bir öneme sahip bulunmaktadır 


\section{KAYNAKÇA}

Akman, M.S. 1987. Yapı Malzemeleri, İTÜ. İnşaat Fakültesi Matbaası, İstanbul

Ambroise, J., Fournier, A.A., Guillot, B., Pera 1987. J. Convention de Recherche VSG/INSA/ENSMSE. p 62, Lyon, Paris Analiz Raporu 2001. Analiz kod No. 01.03/09-512. ODTÜ, Ankara

Anonim 2002. Ağırnas, Ağırnas Belediyesi Tanıtım Broşürü, Kayseri

Baronio G. Binda L. 1997 Study of the pozzolanicity of s ome bricks and clays, Construction and Building Materials Vol. 11, $\mathrm{N}^{\circ}$ 1, Elsevier Science, pp.70-78

Bénoît O. 1967. Détermination de l'activité pouzzolanique d'une pouzzolane par voie Chimique, Bull liaison labo. P. et Ch. $\mathrm{N}^{\circ} 26$, PP D1-D5.

Bich, C. 2005. Contribution a l'Etude de L'Activation Thermique du Kaolin: Evolution de la Structure Cristallographique et Activite Pouzzolanique, L'Institut National des Sciences Appliquees de Lyon. Doct. These, No d'ordre 2005-ISAL0009, Lyon

Böke, H. Dr., Akkurt. S. Dr., İpekoğlu, B. 2004. Tarihi Yapılarda Kullanılan Horasan Harcının Özellik leri, Yapı Dergisi No: 269, İstanbul

Cabane, N. 2004. Sols Traites À La Chaux et aux Liants Hydrauliques: Contribution à l'identification et à l'analyse des éléments perturbateurs de la sta bilisation, These, Docteur de l'Université Jean Monnet et de l'Ecole Nationale Supérieure des Mines de St-Etienne, France

Cerny'.R., Kunca, A., Tydlita't, V., Drchalova', J., Rovnanı kova, R. 2006. Effect of pozzolanic admixtures on mechanical, thermal and hygric properties of lime plasters, Construction and Building Materials 20, 849-857

Cömert, H. 2005 Koramaz'dan A ğırnas'a, Ağırnas'lı Sinan. Ağırnas Belediyesi Yay, s.401, Kayseri

Çelik, K., Kılınçkale, F.M. 2005. Katkı Miktarı, Türünün ve Öğütmenin Çimentonun Dayanım Performansina Etkileri, II. Mühendislik Bilimleri Genç Araştırmacılar Kongresi, MBGAK 2005. 17-19 Kasım 2005, İstanbul

Davidovits, F. 2000 Androstene di Taso E Il Periplo Dell'India, Université de Caen, Pomoerivm 4-5, 2000 ISSN 0945-2354

Frachebourg, J. 1965. Contribution à l'étude de quelques Pouzzolanes naturelles et artificielles en vue de la fabrication des ciments de Pouzzolanes, Thèse présentée à 1'Ecole Polytechnique de l'université de Lausanne pour l'obtention du grade de Docteur ès-sciences techniques. STMAURICE IMPRIMERIE RRODANIQUE S, A. Lausenne

Melo, C.U., Billiong, N. 2004. Activite Pouzzolanique des Dechets de Briqueset Tuiles Cuites, AJST, Science and Engineering Series Vol.5, No.1, pp. 92-100

Postacıoğlu, B.,Çakıroğlu, N., Ortabaşı, N. 1960. Kayseri Puzolanları. İTÜ, Mim.Fak, İstanbul

Postacıoğlu, B. 1969. Yapı Malzemesi Dersleri. İTÜ, İnşaat Fak. Yay, İstanbul
Sanchez-Moral. S., Lugue, L., Canaveras, J. C., Soler, V., Garcia-Guinera, J., Aparicio, A. 2005. Lime pozzolana mortars in Roman catacombs: com position, structures and restoration, Cement and concrete Research 35, 1555-1565.

Shi, C. 2001 An Overview on the Activation of Reactivity of Natural Pozzolans,. Canadian Journal of Civil Engieering. Vol., 28,. 778-786

Urak G., Çelebi, G. 2005. Beypazarı Geleneksel Evlerinde Uygulanan "Tatlı Sıva" Üzerine bir İnceleme, Gazi Üniv., Müh.Mim.Fak. Dergisi, Cilt 20, No 3, 401-409

Zendri, E., Lucchini, V., Biscontin, G., Morabito Matteo, Z 2004 Interaction between Clay an Lime in "cocciopesto" mortars: a Study by SiMAS Spectroscopy, Applied Clay Science 25, 1-7

TS 25 Tras. Türk Standartları Enstitüsü, Nisan 1975.

TS 639 Uçucu Küller. Türk Standartları Enstitüsü, Nisan 1975.

TS 699. Tabii Yapı Taşları-Muayene ve Deney Metodları. Türk Standartları Enstitüsü, Ocak 1987.

TS EN 14579 "Doğal Taşlar-Deney Metotları- Ses Hızı İlerlemesinin Tayini” Türk Standardları Enstitüsü, Şubat 2006. Ankara

ASTMC 618-03 Standart Specification for Coal Fly Ash and Raw or Calcined Natural Pozzolan for Use in Concrete, 